\title{
Blockade of enzyme activity inhibits tissue transglutaminase-mediated transamidation of $\alpha$-synuclein in a cellular model of Parkinson's disease
}

\author{
Robin Verhaar ${ }^{\mathrm{a}, 1, *}$, Cornelis A.M. Jongenelen ${ }^{\mathrm{a}, 1}$, Melanie Gerard $^{\mathrm{b}}$, Veerle Baekelandt ${ }^{\mathrm{c}}$, \\ Anne-Marie Van Dam ${ }^{\mathrm{a}}$, Micha M.M. Wilhelmus ${ }^{\mathrm{a}}$, Benjamin Drukarch ${ }^{\mathrm{a}}$ \\ ${ }^{a}$ Department of Anatomy and Neurosciences, Neuroscience Campus Amsterdam, VU University Medical Center, Amsterdam, The Netherlands \\ ${ }^{\mathrm{b}}$ Laboratory of Biochemistry, Interdisciplinary Research Centre, Katholieke Universiteit Leuven-Kortrijk, Kortrijk, Flanders, Belgium \\ ${ }^{\mathrm{c}}$ Laboratory for Neurobiology and Gene Therapy, Katholieke Universiteit Leuven, Leuven, Flanders, Belgium
}

\section{A R T I C L E I N F O}

\section{Article history:}

Received 28 January 2011

Received in revised form 2 March 2011

Accepted 3 March 2011

Available online xxx

\section{Keywords:}

Tissue transglutaminase

$\alpha$-Synuclein

Neuroblastoma

Parkinson's disease

\begin{abstract}
A B S T R A C T
Transamidation of $\alpha$-synuclein by the $\mathrm{Ca}^{2+}$-dependent enzyme tissue transglutaminase (tTG, EC 2.3.2.13) is implicated in Parkinson's disease (PD). tTG may therefore offer a novel therapeutic target to intervene in PD. Here we first evaluated the potency and efficacy of three recently developed irreversible active-site inhibitors of tTG (B003, Z006 and KCC009) to inhibit tTG activity in vitro and in living cells. In vitro, all compounds were found to be full inhibitors of tTG activity showing a rank order of potency (defined by IC-50 values) of Z006 > B003 > KCC009. Upon Ca ${ }^{2+}$ ionophore (A23187) induced activation of cellular tTG (measured by incorporation of the tTG-specific amine substrate 5-(biotinamido)pentylamine (BAP) into cellular proteins) in neuroblastoma SH-SY5Y cells, only Z006 (0.3-30 $\mu \mathrm{M})$ retained the capacity to completely inhibit tTG activity. Under these conditions B003 (3-300 $\mu \mathrm{M})$ only partially blocked tTG activity whereas KCC009 $(3-100 \mu \mathrm{M})$ failed to affect tTG activity at any of the concentrations used. Z006 $(30 \mu \mathrm{M})$ also blocked the tTG mediated incorporation of BAP into $\alpha-$ synuclein monomers and SDS-resistant multimers in vitro and in $\alpha$-synuclein overexpressing SHSY5Y cells exposed to A23187 or the PD mimetic 1-methyl-4-phenylpyridine (MPP ${ }^{+}$). Moreover, Z006 (30 $\mu \mathrm{M}$ ) substantially reduced formation of SDS-resistant $\alpha$-synuclein multimers in SH-SY5Y cells exposed to A23187 or $\mathrm{MPP}^{+}$in the absence of BAP. We conclude that $\alpha$-synuclein is a cellular substrate for tTG under conditions mimicking PD and blockade of tTG activity counteracts $\alpha$-synuclein transamidation and aggregation in vitro and in living cells. Moreover, our cell model appears an excellent readout to identify candidate inhibitors of intracellular tTG.
\end{abstract}

(c) 2011 Elsevier Ltd. All rights reserved.

\section{Introduction}

Parkinson's disease (PD) is a neurological movement disorder, characterized by progressive degeneration of catecholaminergic neurons in various brain areas, in particular the substantia nigra pars compacta (SNpc) and locus coeruleus (Braak et al., 2003). Another hallmark of PD is the presence of large intraneuronal proteinaceous inclusions called Lewy bodies (LBs) and Lewy neurites (LNs). These inclusions consist primarily of highly aggregated forms of the $\alpha$-synuclein protein (Spillantini et al., 1997). Similar $\alpha$-synuclein containing inclusions occur in a number of other neurodegenerative disorders, including dementia

\footnotetext{
* Corresponding author at: VU University Medical Center, Neuroscience Campus Amsterdam (NCA), Department of Anatomy and Neurosciences, Van der Boechorststraat 7, 1081 BT Amsterdam, The Netherlands. Tel.: +31 20444 8096; fax: +31204448100 .

E-mail address: r.verhaar@vumc.nl (R. Verhaar).

${ }^{1}$ Both authors contributed equally to this work.
}

with Lewy Bodies (DLB) and multiple system atrophy, which, together with PD, are commonly referred to as synucleinopathies (Galvin et al., 2001).

$\alpha$-Synuclein is a relatively small acidic protein consisting of 140 amino-acids with an apparent size of about $14 \mathrm{kDa}$. While its physiological function remains largely elusive, $\alpha$-synuclein is associated with the presynaptic nerve terminal, where it is involved in priming and recycling of synaptic vesicles (Chandra et al., 2005; Gitler et al., 2008; Larsen et al., 2006). $\alpha$-Synuclein belongs to the family of so-called intrinsically disordered proteins and has been reported to exist in an unfolded conformation in vitro, which, upon negatively charged phospholipid binding, adopts an $\alpha$-helical conformation (Weinreb et al., 1996; Eliezer et al., 2001; Ulmer et al., 2005). This unfolded conformation makes $\alpha$-synuclein prone to misfolding, allowing it to readily form multimers and protofibrils that eventually fibrilize into insoluble aggregates which constitute the core of LBs and LNs (Conway et al., 2000).

The importance of $\alpha$-synuclein for PD pathogenesis is emphasized by the fact that increased $\alpha$-synuclein expression

0197-0186/\$ - see front matter (c) 2011 Elsevier Ltd. All rights reserved. doi:10.1016/j.neuint.2011.03.004 
induced by multiplication of the $\alpha$-synuclein gene can cause rare familial forms of $\mathrm{PD}$, whereas missense point mutations that stimulate protein misfolding, such as A30P, A53T and E46K, give rise to autosomal dominant early-onset forms of PD (Polymeropoulos et al., 1997; Kruger et al., 1998; Zarranz et al., 2004; Chartier-Harlin et al., 2004; Ibanez et al., 2004). In addition, several other factors have been implicated in $\alpha$-synuclein aggregation, such as the presence of polycations and divalent metal ions, and post-translational modifications, including oxidation, phosphorylation, nitrosylation and transamidation (reviewed in (Uversky, 2007))

Tissue transglutaminase (tTG, EC 2.3.2.13), also known as TG2, is the best characterized member of the transglutaminase (TG) family of enzymes, which consists of eight catalytically active members and one inactive member (Griffin et al., 2002; Lorand and Graham, 2003). Like other TGs, tTG is a thiol-sensitive, calciumdependent enzyme that catalyzes several reactions, in particular the acyl-transfer between the $\gamma$-carboxamide group of a polypeptide bound glutamine and the $\varepsilon$-amino group of a polypeptide bound lysine or low molecular weight (poly)amines such as putrescine, spermine and spermidine (Lorand and Graham, 2003; Griffin et al., 2002). This so-called transamidation reaction results in the formation of covalent, highly protease resistant $\varepsilon-(\gamma-$ glutamyl)lysine isopeptide cross-links or ( $\gamma$-glutamyl)polyamine bonds, respectively. Besides the increased expression of tTG protein in the SNpc and elevated levels of tTG protein in cerebrospinal fluid (CSF) of PD patients (Andringa et al., 2004; Vermes et al., 2004), tTG induced cross-links in soluble $\alpha$-synuclein monomers and (small)multimers are also detected in the SNpc of PD patients and cross-links are found in LBs from patients suffering from PD and DLB (Andringa et al., 2004; Junn et al., 2003; Nemes et al., 2009). These findings strongly implicate tTG activity in $\alpha-$ synuclein aggregation and thus in the pathogenesis of synucleinopathies.

Alike the situation in the PD brain, tTG activity induces crosslinks in $\alpha$-synuclein, in vitro (Konno et al., 2005; Schmid et al., 2009; Segers-Nolten et al., 2008). Interestingly, intra-molecularly cross-linked $\alpha$-synuclein has recently been shown to function as a seed that initiates and promotes $\alpha$-synuclein misfolding (Nemes et al., 2009). As a result of all these findings, tTG is increasingly recognized as a potential therapeutic target to counteract protein misfolding in PD (Wilhelmus et al., 2008). Surprisingly, however, although established in a test-tube setting, tTG-catalyzed transamidation of $\alpha$-synuclein in more relevant, i.e. cellular model systems, is still subject of debate (Junn et al., 2003; Suh et al., 2004). Moreover, the lack of selective tTG inhibitors has seriously hampered evaluation of tTG as a potential therapeutic target. With the recent synthesis of a number of selective pepidergic irreversible active-site inhibitors of tTG, this problem has largely been overcome (Choi et al., 2005; Hausch et al., 2003; McConoughey et al., 2010; Schaertl et al., 2010).

The SH-SY5Y neuroblastoma is a well-characterized catecholaminergic cell line often used as a neuronal model in PD research (Schule et al., 2009). Upon treatment with all-transretinoic acid (RA), SH-SY5Y cells stop dividing and show signs of neuronal differentiation and express a large amount of tTG protein (Pahlman et al., 1984; Zhang et al., 1998). These properties make the cell line ideally suited to identify targets of tTG activation in a live cell setup. Therefore, in the present study we used RA treated wild-type and $\alpha$-synuclein overexpressing SH-SY5Y cells to study the effect of a number of recently developed tTG inhibitors on tTG activity and transamidation of $\alpha$-synuclein. Our results demonstrate that $\alpha$-synuclein is an intracellular substrate for tTG and that a relatively simple cellular model can be used to identify promising drugs to counteract this pathogenetically important interaction.

\section{Materials and methods}

\subsection{Materials}

Poly-Horseradish Peroxidase (HRP) was obtained from Sanquin (Amsterdam, The Netherlands). Dithiothreitol (DTT) was purchased from Promega (Leiden, The Netherlands). 5-(Biotinamido)pentylamine (BAP), streptavidin coupled to agarose and the Bicinchoninic acid (BCA) Protein Assay Kit were purchased from Pierce (Rockford, IL, USA). Dimethylsulfoxide (DMSO) was purchased from Riedel-de Haën (Seelze, Germany). Standard 96-well and Maxisorp immuno 96well flat-bottom plates were obtained from Nunc (Roskilde, Denmark). 12-well culture plates were obtained from Corning (Corning, NY, USA) and black 96-well plates were purchased from Greiner (Alphen aan den Rijn, The Netherlands). SHSY5Y cells were obtained from the American Type Culture Collection (ATCC, Manassas, CA, USA). Fetal Bovine Serum (FBS) was obtained from Cambrex (Verviers, Belgium). All other cell culture media and supplements were obtained from Invitrogen/Gibco (Paisly, UK). Bovine serum albumin (BSA), o-phenylenediamine dihydrochloride (OPD), 1-methyl-4-phenyl-pyridinium $\left(\mathrm{MPP}^{+}\right)$, ethylenediaminetetraacetic acid (EDTA), ethylene glycol tetraacetic acid (EGTA), 4(2-hydroxyethyl)-1-piperazineethanesulfonic acid (HEPES), (3-(4,5dimethylthiazol-2-yl)-2,5-diphenyltetrazolium bromide (MTT) and all other reagents were obtained from Sigma (St. Louis, MO, USA). Mouse monoclonal antibody 211 directed against human $\alpha$-synuclein was purchased from Santa Cruz (Santa Cruz, CA, USA). Mouse monoclonal antibodies Ab-2 (clone TG100) and Ab-3 (clones CUB 7402 + TG100) directed against guinea pig tTG, were obtained from Thermo Scientific (Fremont, CA, USA). Goat derived polyclonal antibody directed against guinea pig tTG was purchased from Millipore (Haarlerbergweg, Amsterdam, The Netherlands). Mouse monoclonal antibody AC-15 directed against amino acids 1-15 of Xenopus laevis $\beta$-actin was purchased from Abcam (Cambridge, MA, USA). B003 (Boc-DON-Gln-Ile-Val$\mathrm{OMe}$ ) and Z006 (Z-DON-Val-Pro-Leu-OMe) were purchased from Zedira GmbH (Darmstadt, Germany). Cbz-Gln-tyrosyl-halo-dihydroisoxazole KCC009 was a kind gift of Alvine Pharmaceuticals, Inc. (San Carlos, CA, USA).

\subsection{Cell culture}

SH-SY5Y cells were cultured at $37^{\circ} \mathrm{C}$, under $5 \% \mathrm{CO}_{2}$ in air in a $1: 1$ mixture of Eagle's minimum essential medium and Ham's F12 nutrient mixture, containing $10 \%$ FBS, $2.5 \mathrm{mM}$ L-glutamine, 1/100 non-essential amino acids and $1 \mathrm{mM}$ sodium pyruvate. Cells were plated in 12 -well plates $\left(25,000\right.$ cells $\left./ \mathrm{cm}^{2}\right)$. After $24 \mathrm{~h}$, the medium was removed and replaced by cell culture medium containing $3 \%$ FBS and $20 \mu$ M RA (Sigma). Six days after RA administration, cells were used for cellular tTG activity measurements.

\subsection{In vitro tTG activity assay}

In vitro tTG activity was measured essentially as described by Jeitner et al. (2001), with few modifications. In short, reaction buffer (100 mM HEPES-HCl, $20 \mathrm{mM}$ DTT, $40 \mathrm{mM} \mathrm{CaCl}, \mathrm{pH}$ 8.0) was incubated in a black 96 -well plate at $37^{\circ} \mathrm{C}$ for $30 \mathrm{~min}$. Freshly prepared monodansylcadaverine (CAD-DNS, Sigma), in HEPES-HCl, pH 8.0 and $1-N$-(carbobenzoxy-L-glutaminylglycyl)-5-N-(5' $N^{\prime} N^{\prime}$-dimethylaminonaphthalenesulfonyl) diamidopentane (CGG-DNS, Zedira) was added to each well to a final concentration of $10 \mu \mathrm{M}$ and $200 \mu \mathrm{M}$, respectively. The mixture was incubated $15 \mathrm{~min}$ prior to the addition of inhibitors. Finally, $3 \mu \mathrm{g} / \mathrm{ml}$ human recombinant tTG (Zedira) in a $100 \mathrm{mM}$ HEPES buffer (containing $10 \mathrm{mM}$ DTT, $0.5 \mathrm{mM}$ EDTA and $10 \mu \mathrm{g} / \mathrm{ml}$ BSA, pH 8.0) was added. The relative fluorescence enhancement was measured kinetically in a fluorimeter (BMG, Germany) for $4 \mathrm{~h}$ at $260 \mathrm{~nm}$ (excitation) and $530 \mathrm{~nm}$ (emission) at $37^{\circ} \mathrm{C}$. Results where corrected for background fluorescence, which was measured in samples where tTG was omitted from the reaction.

\subsection{Cellular tTG activity assay}

For cellular tTG activity measurements, incorporation of BAP into proteins was determined in SH-SY5Y cells, as described previously by Zhang et al. (1998) with slight modifications. All cell incubation steps were performed at $37{ }^{\circ} \mathrm{C}$ and under $5 \%$ $\mathrm{CO}_{2}$ in air. SH-SY5Y cells were washed once with phosphate buffered saline (PBS) and incubated thereafter for $4 \mathrm{~h}$ with culture media containing $1 \mathrm{mM}$ BAP. Subsequently, without changing medium, the cells were preincubated for $15 \mathrm{~min}$ with various tTG inhibitors (dissolved in dimethyl sulfoxide (DMSO) as $0.1 \mathrm{M}$ stock solutions), or solvent at appropriate concentrations, prior to addition of $10 \mu \mathrm{M}$ of the $\mathrm{Ca}^{2+}$ ionophore $\mathrm{A} 23187$ (Sigma) for $40 \mathrm{~min}$, or, depending on the experiment, 1 $5 \mathrm{mM} \mathrm{MPP}^{+}$for $24 \mathrm{~h}$. The cells were then carefully washed twice with cold PBS and sonicated (Branson sonifier, Danbury, CT, USA) in $400 \mu$ l ice-cold homogenizing buffer $(50 \mathrm{mM}$ Tris, $150 \mathrm{mM} \mathrm{NaCl}$, pH 7.4, containing $1 \mathrm{mM}$ EDTA, $0.1 \mathrm{mM}$ phenylmethylsulphonyl fluoride (PMSF) and $1 \mu \mathrm{g} / \mathrm{ml}$ of aprotinin/pepstatin). The protein concentrations of the lysates were determined with the BCA assay and either immediately used for detection of tTG activity, or stored at $-20^{\circ} \mathrm{C}$. The use of frozen samples did not affect any of the results in the following detection method (data not shown). 
For detection of tTG activity, 96-well Maxisorp plates were incubated with $50 \mu$ of coating buffer (50 mM Tris, $150 \mathrm{mM} \mathrm{NaCl}, 5 \mathrm{mM}$ EGTA, $5 \mathrm{mM}$ EDTA, pH 7.4), followed by $1 \mu \mathrm{g}$ of cell lysate and incubated overnight at $4{ }^{\circ} \mathrm{C}$.

After this step, $200 \mu \mathrm{l}$ of incubation buffer $(50 \mathrm{mM}$ Tris- $\mathrm{Cl}, 80 \mathrm{mM} \mathrm{NaCl}, 2.5 \%$ BSA, $0.01 \%$ sodium dodecyl sulfate (SDS) and $0.01 \%$ Tween-20, $\mathrm{pH} 7.4$ ) was added. Incubation was continued for $2 \mathrm{~h}$ at $37^{\circ} \mathrm{C}$. After this period, wells were washed three times with $200 \mu$ l washing buffer ( $50 \mathrm{mM}$ Tris-Cl, $80 \mathrm{mM} \mathrm{NaCl}, 0.5 \% \mathrm{BSA}$ $0.01 \%$ Tween-20, pH 7.4), followed by incubation with $100 \mu \mathrm{l}$ of $0.1 \mu \mathrm{g} / \mathrm{ml}$ streptavidin conjugated Poly-HRP (Sanquin), diluted in wash buffer over $1 \mathrm{~h}$ at room temperature (RT). Subsequently, wells were washed three times with washing buffer and incubated in OPD-solution $(0.6 \mathrm{mg} / \mathrm{ml} \mathrm{OPD}, 35 \mathrm{mM}$ citric acid, $50 \mathrm{mM} \mathrm{Na}_{2} \mathrm{HPO}_{4}, \mathrm{pH} 5.0$ ) containing $0.01 \%$ hydrogen peroxide for $30 \mathrm{~min}$ at $\mathrm{RT}$. The reaction was stopped by adding $1 \mathrm{M} \mathrm{H}_{2} \mathrm{SO}_{4}$. Absorbance was measured on a microplate reader (SPECTRAmax 250, Molecular Devices, Sunnyvale, CA, USA) at a wavelength of $490 \mathrm{~nm}$ and was corrected for background, which was defined as the absorbance in cellular extracts obtained from experiments where BAP had been omitted from the culture medium.

\subsection{In vitro transamidation of $\alpha$-synuclein by $t T G$}

In vitro tTG catalyzed transamidation reactions were performed with $1 \mu \mathrm{M}$ recombinant human tTG (Zedira) and $50 \mu \mathrm{M}$ recombinant human $\alpha$-synuclein (rPeptide, Bogart, GA, USA) in buffer containing $1 \mathrm{mM}$ BAP, $10 \mathrm{mM}$ Tris-Cl, $50 \mathrm{mM}$ $\mathrm{NaCl}, 1 \mathrm{mM} \mathrm{CaCl}$ and $10 \mathrm{mM}$ DTT, pH 7.4 for $30 \mathrm{~min}$ at $37^{\circ} \mathrm{C}$. The transamidation reaction was started by the addition of tTG. If drugs were used (EDTA or Z006), they were added $5 \mathrm{~min}$ prior to addition of tTG. The reaction was stopped by the addition of TBST ( $10 \mathrm{mM}$ Tris- $\mathrm{Cl}, 150 \mathrm{mM} \mathrm{NaCl}, 0.1 \%$ Tween-20, pH 7.4), containing $1 \mathrm{mM}$ EDTA. BAP labelled protein species were precipitated with $25 \mu \mathrm{l}$ streptavidin coupled to agarose slurry (Pierce) for $1 \mathrm{~h}$ at RT. After 5 subsequent washing steps with TBST, the samples were heated for $10 \mathrm{~min}$ at $95{ }^{\circ} \mathrm{C}$ in Laemmli sample buffer (SB) (Laemmli, 1970) containing $10 \mathrm{mM}$ DTT.

\subsection{Cellular transamidation of $\alpha$-synuclein by $t T G$}

SH-SY5Y cells stably overexpressing $\alpha$-synuclein (SH-SY5Y/Syn) were generated as described (Gerard et al., 2010) and cultured using the same procedure and cell density as used for wild type (WT) SH-SY5Y cells in 6-well plates for a total of 6 days. Thereafter, cells were, either incubated with solvent, or treated for $24 \mathrm{~h}$ with $250 \mathrm{nM}$ A23187 or $5 \mathrm{mM} \mathrm{MPP}$, with or without the simultaneous addition of $30 \mu \mathrm{M}$ Z006. After two washing steps with PBS, cells were lysed in RIPA buffer (50 mM Tris-Cl, $150 \mathrm{mM} \mathrm{NaCl}, 1 \% \mathrm{NP}-40,0.1 \%$ SDS, 1 mM EDTA, pH 7.4) containing $0.1 \mathrm{mM}$ PMSF and $1 \mu \mathrm{g} / \mathrm{ml}$ of aprotinin/pepstatin and subjected to sonication to disrupt DNA strands. Protein concentrations were then determined with BCA and lysates were boiled in SB for subsequent immunoblot analysis.

For biotin labeling experiments, $1 \mathrm{mM}$ BAP was added simultaneously with $250 \mathrm{nM}$ A23187 or $5 \mathrm{mM} \mathrm{MPP}{ }^{+}$in the presence or absence of $30 \mu \mathrm{M} Z 006$ for $24 \mathrm{~h}$ After lysis, $400 \mu \mathrm{g}$ protein per condition was used for subsequent streptavidin precipitation as described for the in vitro BAP labeling experiments.

\subsection{SDS-PAGE and immunoblot analysis}

Protein fractions obtained from cell lysates or streptavidin precipitations were subjected to $12 \%$ SDS-poly acrylamide gel electroforesis (PAGE) and transferred to polyvinylidene fluoride (PVDF) membranes via immunoblotting. After blocking the membranes for $30 \mathrm{~min}$ in TBST containing 5\% non-fat skimmed milk (ELK) (Campina, Woerden, Utrecht, The Netherlands), membranes were probed with primary antibodies $211, \mathrm{Ab}-3$ and AC-15, where appropriate, in TBST containing $2.5 \%$ non-fat skimmed milk. Secondary goat anti-mouse HRP-coupled antibody (DAKO, Heverlee, Belgium) was used as secondary antibody. After washing the membranes three times in TBS $(10 \mathrm{mM}$ Tris- $\mathrm{Cl}, 150 \mathrm{mM} \mathrm{NaCl}, \mathrm{pH} 7.4)$, proteins were visualized with the Supersignal West Dura extended duration substrate (Pierce) and imaged using the Chemidoc XRS imaging system (Bio-Rad, Veenendaal, The Netherlands)

\section{8. tTG sandwich enzyme-linked immunosorbent assay (ELISA)}

In order to measure cellular tTG concentrations in SH-SY5Y/Syn cells that were, either incubated with solvent, or treated for $24 \mathrm{~h}$ with $250 \mathrm{nM}$ A23187 or $5 \mathrm{mM}$ $\mathrm{MPP}^{+}$, in the presence or absence of $30 \mu \mathrm{M}$ Z006, cells were lysed in RIPA and subjected to ELISA essentially as described by us (Breve et al., 2008). In short, 96well maxisorp plates (NUNC) were incubated with goat derived polyclonal antibodies directed against guinea pig tTG (Millipore) at a dilution of $1 / 1000$ for $16 \mathrm{~h}$ at $4{ }^{\circ} \mathrm{C}$ in coating buffer $\left(50 \mathrm{mM} \mathrm{Na}_{2} \mathrm{CO}_{3}, \mathrm{pH} 9.2\right)$. Plates were rinsed once with wash buffer $\left(0.5 \mathrm{M} \mathrm{NaCl}, 10 \mathrm{mM} \mathrm{Na}_{2} \mathrm{HPO}_{4}, 0.1 \%(\mathrm{v} / \mathrm{v})\right.$ Tween-20, pH 7.2) and subsequently blocked for $1 \mathrm{~h}$ at RT with $200 \mu \mathrm{l} /$ well wash buffer containing $0.5 \%$ BSA. After rinsing the plates three times with wash buffer, $100 \mu \mathrm{l} /$ well of $10 \mu \mathrm{g} / \mathrm{ml}$ cell lysate, diluted in wash buffer, was incubated overnight at $4{ }^{\circ} \mathrm{C}$. After washing, $100 \mu \mathrm{l} /$ well wash buffer containing $1 \mu \mathrm{g} / \mathrm{ml}$ monoclonal antibody Ab-2 (Thermo Scientific) was added for $1 \mathrm{~h}$ at RT. Subsequently, wells were incubated with wash buffer containing $100 \mu \mathrm{l}$ of $1 \mu \mathrm{g} / \mathrm{ml}$ biotinylated goat anti-mouse IgG $(\mathrm{H}+\mathrm{L})$
(Jackson, Newmarket, Suffolk, England), followed by incubation with $100 \mu \mathrm{l}$ wash buffer containing $0.1 \mu \mathrm{g} / \mathrm{ml}$ streptavidin poly-HRP (Sanquin), each for $1 \mathrm{~h}$ at room temperature. After final washing steps, $100 \mu \mathrm{l} /$ well OPD-solution containing $0.01 \%$ hydrogen peroxide was added and incubated at RT for $15 \mathrm{~min}$. The reaction was stopped by the addition of $100 \mu \mathrm{l} /$ well $1 \mathrm{M} \mathrm{H}_{2} \mathrm{SO}_{4}$ and absorbance values were determined at $490 \mathrm{~nm}$ using a SPECTRAmax 250 microplate reader.

\subsection{Cell viability assay}

Under normal growth conditions, SH-SY5Y cells were cultured in 96-well cell culture plates (Nunc). A final concentration of $0.5 \mathrm{mg} / \mathrm{ml}$ MTT was added to each well and was allowed to incubate for $45 \mathrm{~min}$ at $37^{\circ} \mathrm{C}$ under $5 \% \mathrm{CO}_{2}$ in air. Thereafter, the medium was removed and replaced by $200 \mu \mathrm{l}$ of DMSO to which $0.5 \%$ (v/v) FBS had been added. After formazan solubilization by vibration on a plate shaker, the absorbance of each well was measured at $540 \mathrm{~nm}$ using the SPECTRAmax 250 microplate reader, as described previously (Drukarch et al., 1996). Absorbance data were calculated by subtracting the mean of background readings obtained from identical incubations in the absence of cells.

\subsection{Statistics}

To calculate IC-50 values, concentration response curves were fitted by nonlinear regression using a four-parameter hill slope equation with the software package Graphpad Prism 5 (La Jolla, CA, USA). Statistical analysis was performed with the software package Graphpad Prism 5, using one-way analysis of variance (ANOVA) with Bonferroni's correction of P values for multiple comparison. For MTT analysis, Student's $t$-test was used. A $P$-value less than 0.05 was considered statistically significant.

\section{Results}

\subsection{In vitro and cellular inhibition of tTG activity}

In the current study, we used recently developed peptide based irreversible active-site inhibitors of tTG i.e. B003, Z006 and KCC009 (Choi et al., 2005; Schaertl et al., 2010). Whereas both B003 and Z006 employ a 6-diazo-5-oxo-norleucine (DON) reactive group, KCC009 has a dihydro-isoxazole group for active-site inhibition of tTG (Fig. 1A). The results from our in vitro test, which is based on the tTG mediated formation of the highly fluorescent reaction product CGG-DNS-CAD-DNS from CGG-DNS and CAD-DNS, show that all three drugs inhibited tTG activity with equal efficacy, but with different potency. Thus, under the experimental conditions used, Z006 displayed an IC-50 of $\pm 0.04 \mu \mathrm{M}$, reaching maximal inhibition at $\pm 0.3 \mu \mathrm{M}$ (Fig. 2A). Compared to Z006, B003 was found to be less potent (IC-50 $\pm 0.3 \mu \mathrm{M})$, with a maximally effective concentration of $\pm 3 \mu \mathrm{M}$ (Fig. 2A). KCC009, however, was the least potent with an IC-50 of $\pm 1 \mu \mathrm{M}$ and a maximally effective concentration of $\pm 10 \mu \mathrm{M}$ (Fig. 2A)

In contrast to the in vitro data, the results from our cellular model clearly distinguished between the different drugs on both potency and efficacy of tTG inhibition. In fact, to our knowledge, our data are among the first to establish a clear concentrationeffect relationship of pharmacologic tTG inhibition in cells, although using a different experimental setup, effects of inhibitors on tTG activity in SH-SY5Y cells have been reported previously (Beck et al., 2006; Lesort et al., 2003; Singh et al., 2003). This model, originally characterized by Zhang et al. (1998), is based on detection of tTG-mediated covalent incorporation of the amine donor BAP into cellular proteins following activation of transamidation activity by a rise in intracellular $\mathrm{Ca}^{2+}$ concentration as a result of exposure of the cells to $\mathrm{Ca}^{2+}$ ionophores like $\mathrm{A} 23187$.

Under these experimental conditions, Z006 induced a concentration-dependent inhibition of cellular tTG activity with an IC-50 of $\pm 0.7 \mu \mathrm{M}$ and near complete blockage of BAP incorporation at a concentration of $10 \mu \mathrm{M}$ (Fig. 2B). Although similar to the in vitro measurements, B003 was found to be approximately 10-fold less potent than Z006 in inhibiting tTG activity in SH-SY5Y cells (IC$50 \pm 7 \mu \mathrm{M}$ ), it demonstrated considerable less efficacy in the cell model, reaching $75 \%$ enzyme inhibition at a maximally effective 
A

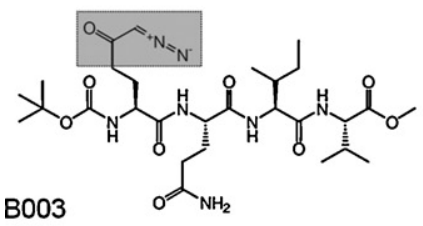<smiles>O=C(NC(Cc1ccc(O)cc1)C(=O)NCC1CC2CCC1O2)OCc1ccccc1</smiles>

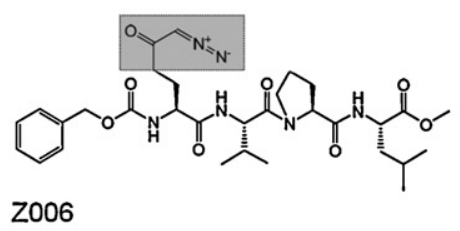
Z006

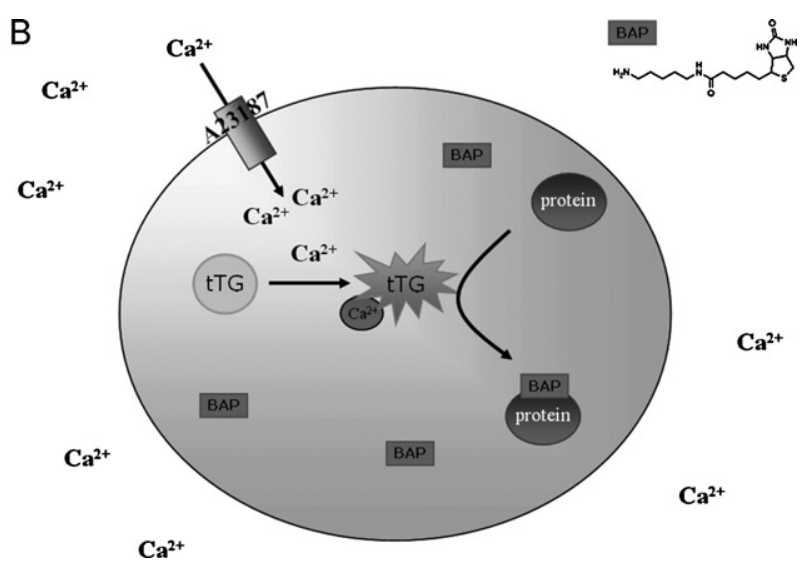

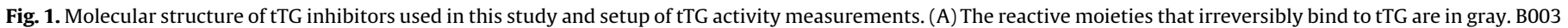

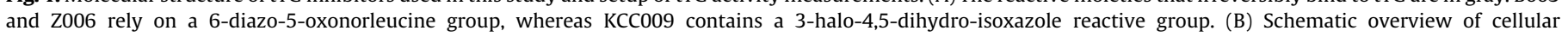

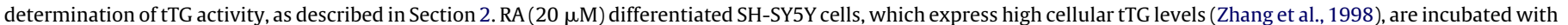

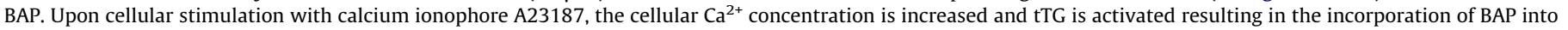
proteins.

concentration of $300 \mu \mathrm{M}$ (Fig. 2B). In contrast to the DON based inhibitors Z006 and B003 and the in vitro measurements, the dihydroisoxazole based compound KCC009 failed to significantly affect cellular tTG activity in concentrations up to $100 \mu \mathrm{M}$ (Fig. 2B). At higher concentrations of KCC009, the amount of DMSO ( $>1 \%)$ required to completely dissolve the compound interfered with the cellular tTG assay.

In the absence of A23187, only small amounts of BAP bound to proteins. This non-specific (i.e. non tTG-mediated) BAP incorporation was not influenced by the tTG inhibitors, who also did not affect cellular viability at any of the concentrations tested (data not shown). Moreover, BAP incorporation due to exposure to A23187 was completely blocked by co-incubation with the $\mathrm{Ca}^{2+}$ chelating agent EDTA at a concentration of $1 \mathrm{mM}$ (data not shown).

\section{2. $\alpha$-Synuclein is a substrate of tTG in vitro}

The above mentioned data indicated that (1) cellular BAP incorporation properly reflected tTG activity in A23187-treated cells, (2) the assay method differentiates between alleged tTG inhibitors in their potency and efficacy to block intracellular tTG activity, and (3) protein-bound BAP is an indicator of newly formed cross-links. We therefore wondered whether we could use this polyamine to develop a cellular assay that measures the effect of inhibition of tTG activity on $\alpha$-synuclein transamidation. For this purpose, we first investigated BAP incorporation into human recombinant $\alpha$-synuclein in the presence of $\mathrm{Ca}^{2+}$ activated recombinant human tTG in vitro. Immunoblot analysis, following streptavidin precipitation of BAP bound $\alpha$-synuclein, revealed both $\alpha$-synuclein monomers as well as SDS-stable multimers (Fig. 3), in line with previous in vitro studies that only used tTG and $\alpha$ synuclein (Junn et al., 2003; Konno et al., 2005; Lashuel et al., 2002; Nemes et al., 2009; Segers-Nolten et al., 2008). Moreover, BAP incorporation into $\alpha$-synuclein was completely blocked via coincubation with the tTG inhibitor Z006 $(30 \mu \mathrm{M})$, or by $\mathrm{Ca}^{2+}$ chelation with EDTA ( $1 \mathrm{mM}$ ) (Fig. 3), whereas no BAP incorporation occurred in the absence of tTG (data not shown).

\section{3. $\alpha$-Synuclein is a cellular substrate of $t T G$}

In an additional set of experiments, we used lentiviral transduced SH-SY5Y cells that stably express human WT $\alpha$ synuclein (characterized previously by Gerard et al. (2010)) and treated these cells with A23187 in the presence of BAP, following differentiation with RA. Upon a short treatment (40 min) of these cells with A23187 $(10 \mu \mathrm{M})$, i.e. the paradigm that was used for determination of the cellular concentration-response curves of tTG inhibitors, no biotinylated $\alpha$-synuclein could be detected.
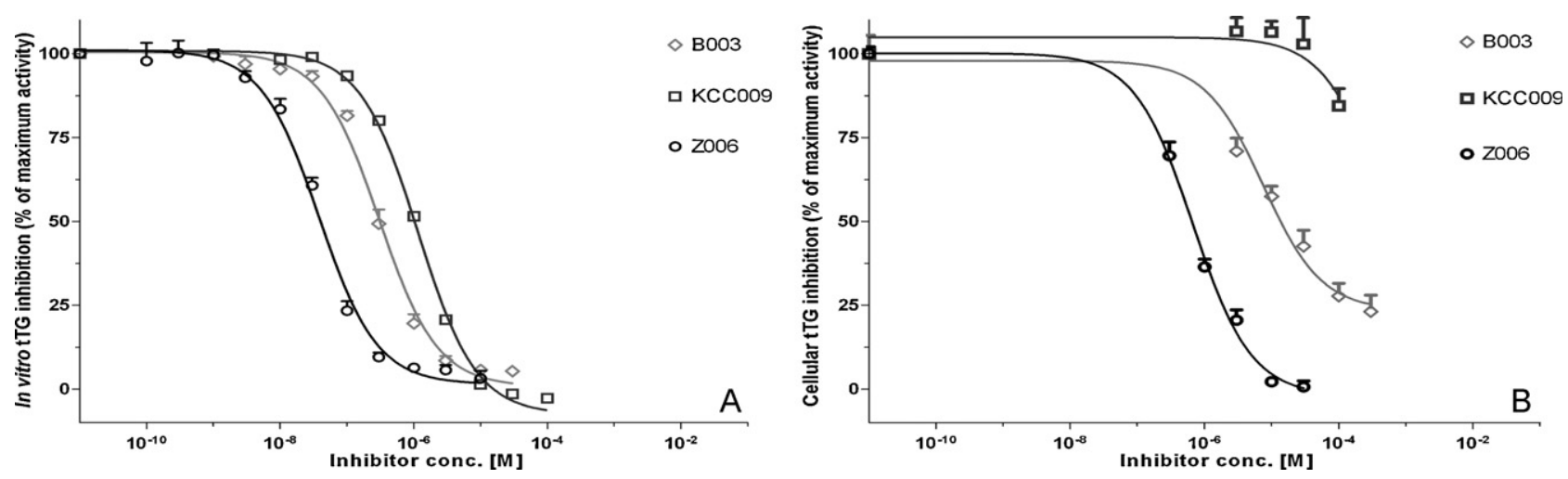

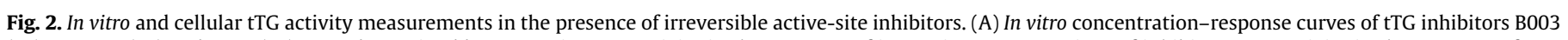

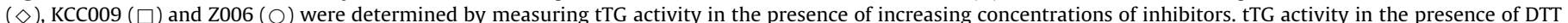

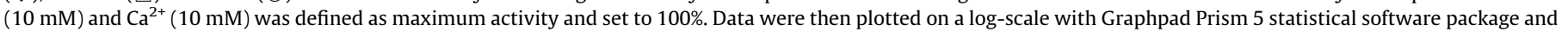

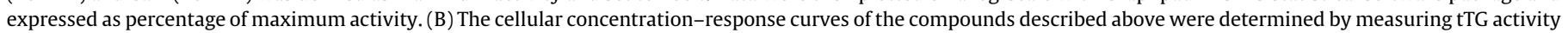

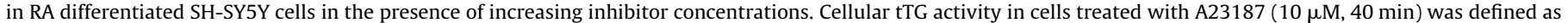

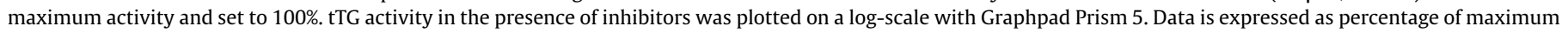

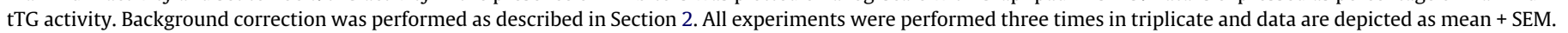


Streptavidin pull-down

IB: $\alpha-S y n u c l e i n$

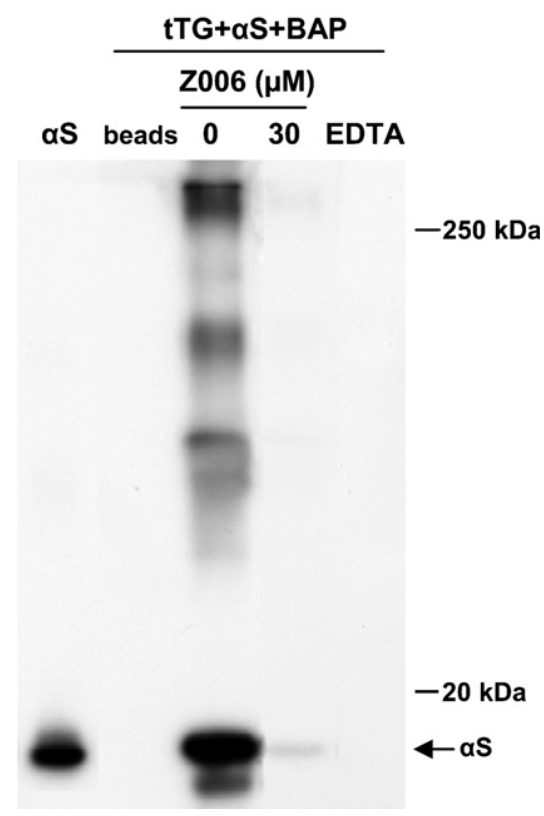

Fig. 3. tTG transamidates $\alpha$-synuclein monomers and multimers in vitro. Human recombinant tTG $(1 \mu \mathrm{M})$ was incubated in the presence of human recombinant $\alpha$ synuclein $(\alpha \mathrm{S})(50 \mu \mathrm{M})$ and BAP $(1 \mathrm{mM})$. Biotinylated proteins were precipitated and analyzed on immunoblot (IB, monoclonal antibody 211). Enzymatic activity of tTG was blocked when Z006 ( $30 \mu \mathrm{M})$ or EDTA (1 mM) was co-incubated during the transamidation reaction. As control for unspecific conjugate binding, empty streptavidin coupled to agarose (beads) was used. Experiment was repeated 3 times with similar results. Typical experiment is shown.

Therefore, a longer incubation time with BAP $(24 \mathrm{~h})$, in combination with reduced A23187 (250 nM) concentrations, was used. Under these circumstances, BAP incorporation could be readily detected in $\alpha$-synuclein monomers and a variety of SDS-stable $\alpha$ synuclein immunoreactive multimers (Fig. 4). Moreover, in the presence of Z006 $(30 \mu \mathrm{M})$, a large reduction in biotinylated $\alpha$ synuclein was observed (Fig. 4).

\section{4. $t T G$-dependent $\alpha$-synuclein transamidation is induced by the PD mimetic MPP ${ }^{+}$}

Given the fact that ionophore-induced calcium mobilization in differentiated SH-SY5Y/Syn cells readily resulted in tTG-dependent $\alpha$-synuclein transamidation and multimerization, we questioned whether this phenomenon also occurs under conditions more relevant to PD. Therefore, we treated the cells with the mitochondrial complex I inhibitor $\mathrm{MPP}^{+}$, an active metabolite of 1methyl-4-phenyl-1,2,3,6 tetrahydropyridine (MPTP) that is commonly used as a toxin to induce PD-like phenomena in several well-established cellular and in vivo PD models (Burns et al., 1983; Heikkila et al., 1984). In line with previous work by Beck et al. (2006), we found that incubation with $\mathrm{MPP}^{+}(1-5 \mathrm{mM})$ for $24 \mathrm{~h}$ induced a concentration-dependent activation of tTG activity in RA-differentiated WT SH-SY5Y cells (Fig. 5A). More importantly, following treatment of RA-differentiated SH-SY5Y/syn cells with $\mathrm{MPP}^{+}(5 \mathrm{mM})$ and BAP $(1 \mathrm{mM})$ for $24 \mathrm{~h}$ and subsequent precipitation of biotinylated proteins, $\alpha$-synuclein monomers and SDSstable $\alpha$-synuclein immunoreactive multimers could be discerned on immunoblot (Fig. 5B), in a pattern similar to that observed upon treatment with A23187 (Fig. 4). Moreover, in the presence of $\mathrm{MPP}^{+}$, co-incubation with $30 \mu \mathrm{M}$ Z006 reduced the levels of biotinylated $\alpha$-synuclein below the detection limit of the assay (Fig. 5B).

\section{Streptavidin pull-down \\ IB: $\alpha$-Synuclein}

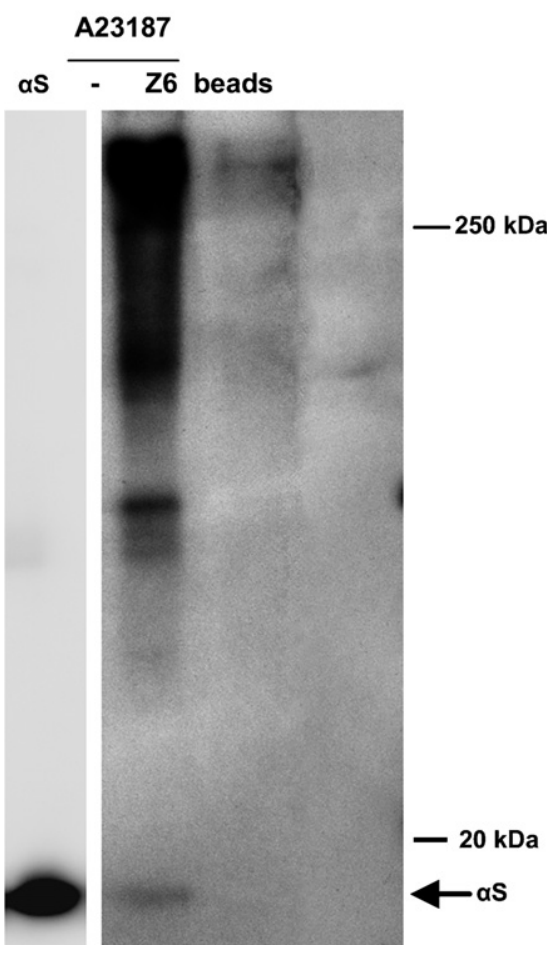

Fig. 4. Cellular $\mathrm{Ca}^{2+}$ influx induces tTG mediated $\alpha$-synuclein transamidation. RA

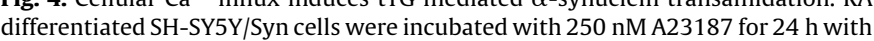
(Z6) or without $(-)$ the presence of Z006 $(30 \mu \mathrm{M})$ as detailed in Section 2. All incubations were performed in the presence of BAP $(1 \mathrm{mM})$. Biotinylated proteins were precipitated and subjected to immunoblot (IB) analysis. $\alpha$-Synuclein $(\alpha S)$ was visualized using monoclonal antibody 211. As control for unspecific conjugate binding, empty streptavidin coupled to agarose (beads) was used. For details see Section 2. Experiment was repeated 3 times with similar results. Typical experiment is shown. Although all samples originate from the same IB, a shorter illumination time was required for human recombinant $\alpha$-synuclein.

\section{5. $\alpha$-Synuclein multimerisation is not dependent on BAP}

In the above set of data, in order to determine whether activation of tTG by either $\mathrm{A} 23187$ or $\mathrm{MPP}^{+}$resulted in newly formed transamidated $\alpha$-synuclein species, we used BAP incorporation as a specific marker for tTG catalyzed crosslinks. A limitation of this approach may be that the presence of polyamines itself is reported to induce $\alpha$-synuclein multimerisation (Antony et al., 2003). To rule out the possibility that $\alpha$-synuclein multimerisation and the effect thereon of tTG inhibition is dependent on the presence of the polyamine BAP, we treated SH-SY5Y/Syn cells with A23187 $(250 \mathrm{nM})$ or $\mathrm{MPP}^{+}(5 \mathrm{mM})$ for $24 \mathrm{~h}$ in the presence or absence of Z006 $(30 \mu \mathrm{M})$. Importantly, BAP was omitted from these experiments. As depicted in Fig. 6A (upper panel), although absent in untreated cells, treatment with A23187 or MPP ${ }^{+}$resulted in the formation of $\alpha$-synuclein positive, SDS-resistant multimers and larger aggregates that did not migrate further than the stack of the SDS-PAGE gel. Co-incubation with Z006 (30 $\mu \mathrm{M})$, however, strongly reduced $\alpha$-synuclein multimer and aggregate formation. In fact, in cells treated with $\mathrm{Ca}^{2+}$ ionophore or $\mathrm{MPP}^{+}$, only mild $\alpha$ synuclein multimerization and aggregate formation was noted in the presence of the tTG inhibitor (Fig. 6A, upper panel).

Finally, to rule out that the inhibitory effect of Z006 on $\alpha$ synuclein transamidation induced by $\mathrm{A} 23187$ or $\mathrm{MPP}^{+}$following prolonged incubation was due to an effect of Z006 on tTG protein expression or processing rather than activity, we quantified total tTG levels in the aforementioned SH-SY5Y/Syn cells with two 


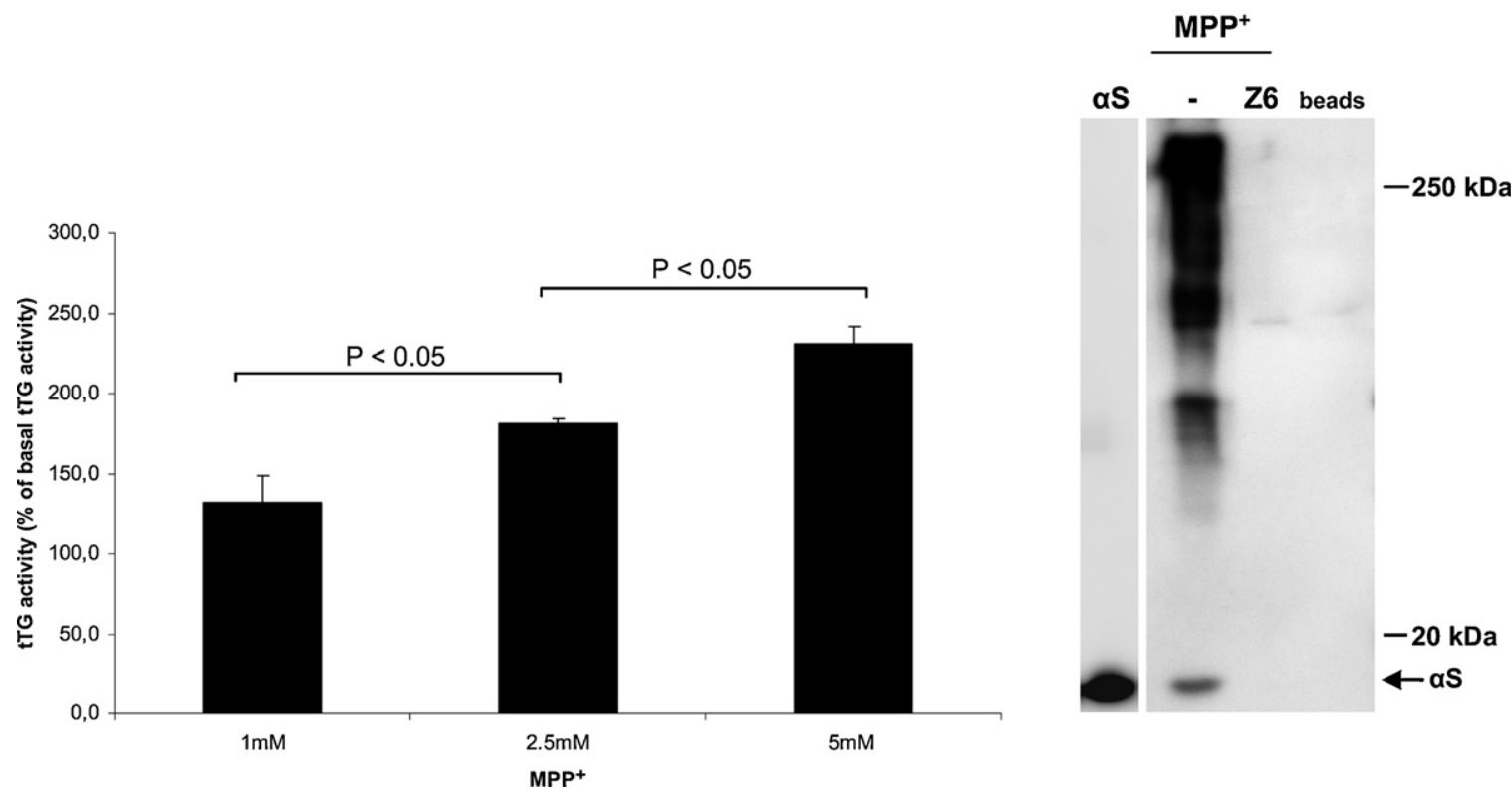

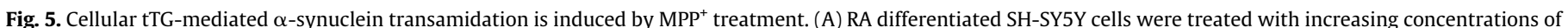

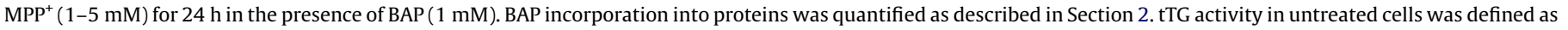

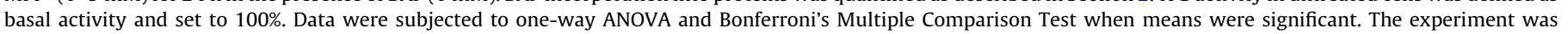

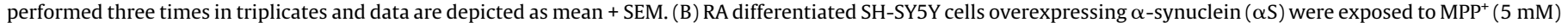

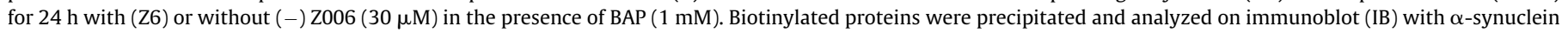

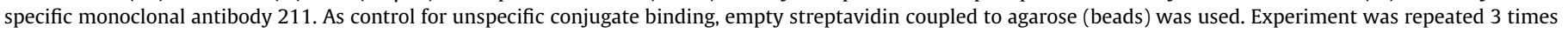
with similar results. Typical experiment is shown.

different approaches. First, tTG levels were estimated on immunoblot, using $\beta$-actin as a loading control (Fig. 6A, lower panel). Second, tTG concentrations were determined with a previously inhouse established tTG specific sandwich-ELISA (Breve et al., 2008) (Fig. 6B). Even though a small decrease in tTG protein levels in A23187 and $\mathrm{MPP}^{+}$treated cells was noted, co-incubation with Z006 $(30 \mu \mathrm{M}$ ) did not significantly alter tTG protein levels (Fig. 6A, lower panel and Fig. 6B). It is important to note that incubation with Z006 $(30 \mu \mathrm{M})$ did not affect cellular viability of SH-SY5Y/Syn cells, as measured with MTT (Fig. 6C).

\section{Discussion}

Post-translational modification by tTG is increasingly recognized as an important stimulatory factor in the aggregation of $\alpha$ synuclein and formation of LBs, as observed in PD and related synucleinopathies (Nemes et al., 2009; Junn et al., 2003; Andringa et al., 2004). Therefore, tTG may represent an attractive target to counteract $\alpha$-synuclein misfolding in neurodegenerative diseases. In the present study, we used a cell model to study the effect of pharmacological inhibition of enzyme activity on the interaction between tTG and $\alpha$-synuclein. We show here for the first time that in neuronally differentiated, $\alpha$-synuclein overexpressing cells, active tTG is able to transamidate cellular $\alpha$-synuclein, resulting in formation of modified monomeric and multimeric $\alpha$-synuclein species which appear similar to those detected by us and others in vitro (Junn et al., 2003; Konno et al., 2005; Schmid et al., 2009; Segers-Nolten et al., 2008) and in PD brain (Andringa et al., 2004). These results underscore the validity of our model. Moreover, our data demonstrate that this interaction between tTG and $\alpha$ synuclein was abolished not only in vitro but also in our cell system in the presence of a recently developed cell-membrane permeable irreversible tTG active-site inhibitor. We also show that this effect of tTG inhibition is not due to drug-induced reduction of tTG protein levels or altered processing of the enzyme. As such, they support and add to previous data reported by Junn et al. who showed blockade of $\alpha$-synuclein aggregation in tTG and synuclein overexpressing cells exposed to high concentrations of the classic but non-specific, competitive tTG inhibitor cystamine (Junn et al., 2003). Therefore, although the methods used do not allow us to conclude that blockade of tTG activity will prevent all $\alpha$-synuclein aggregation under the conditions prevailing in the diseased brain, our results do suggest that the contribution of tTG to this process is amenable to effective pharmacological intervention.

Under physiological circumstances, at least in cultured cells, cytoplasmic $\mathrm{Ca}^{2+}$ levels are too low to induce the transamidation activity of cellular tTG and the enzyme remains catalytically silent (Zhang et al., 1998). This is in line with our results demonstrating no detectable enzymatic interaction between tTG and $\alpha$-synuclein under control, i.e. non-stimulated, condition. However, under pathological conditions such as prevail in PD, cytoplasmic $\mathrm{Ca}^{2+}$ concentration rises to levels which enable tTG to interact with its substrates (Zhang et al., 1998). To specifically identify tTG modified forms of $\alpha$-synuclein under experimental conditions mimicking PD, we activated intracellular tTG either through stimulation of $\mathrm{Ca}^{2+}$ influx with the ionophore A23187 (Fesus et al., 1981) or inhibition of mitochondrial respiration with the PD mimetic MPP ${ }^{+}$ (Beck et al., 2006). Simultaneously, we incubated the cells with the well-characterized labelled synthetic tTG substrate polyamine BAP (Zhang et al., 1998), followed by enrichment of BAP-positive $\alpha$ synuclein protein. Taking into consideration the highly stable (i.e. covalent), protease and detergent resistant nature of tTG-mediated transamidation products (Schmid et al., 2009; Segers-Nolten et al., 2008), this method in principle allows for sensitive determination of all tTG modified $\alpha$-synuclein species into which BAP is incorporated within the time frame of the experiment. However, 

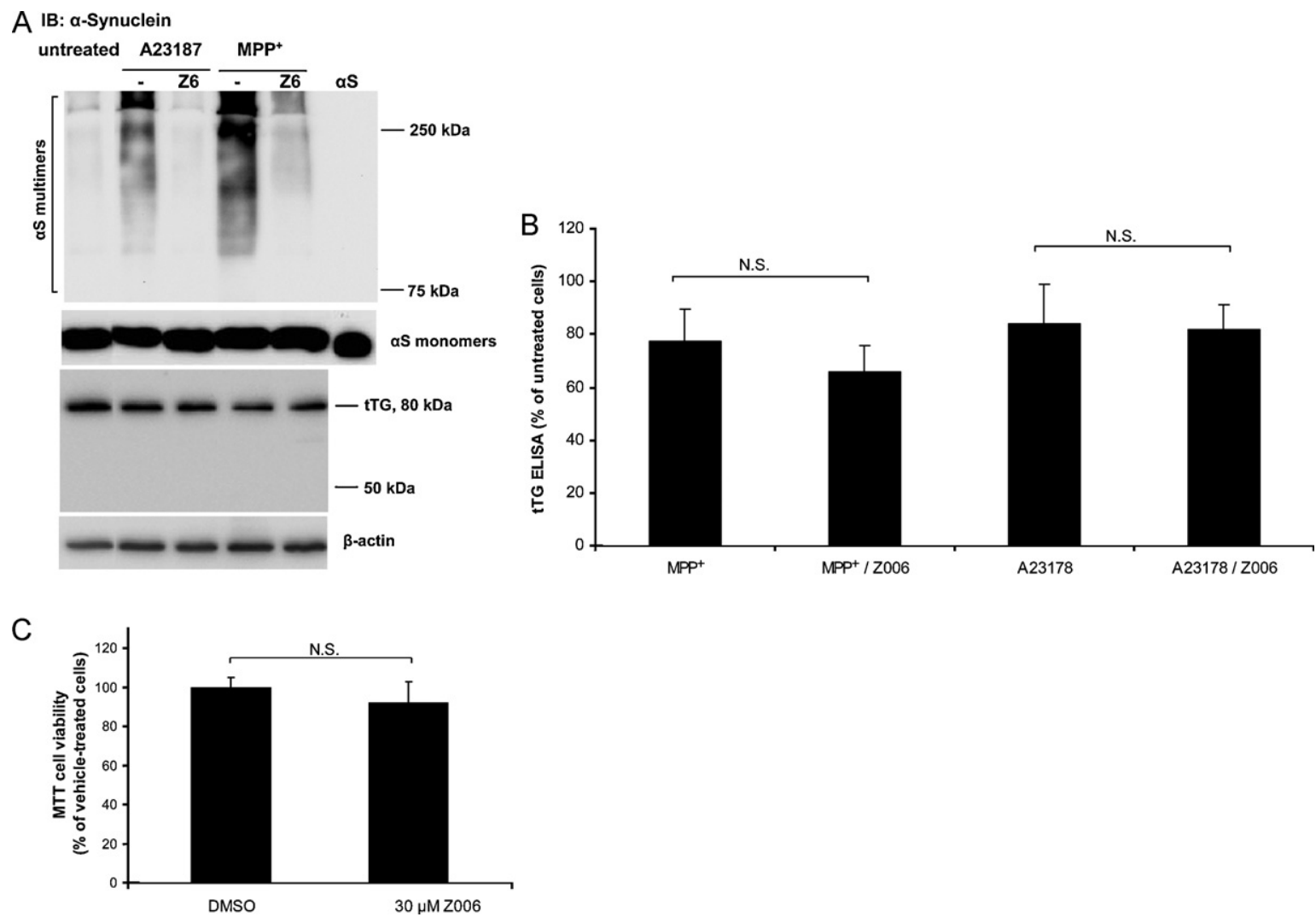

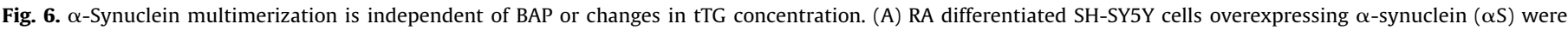

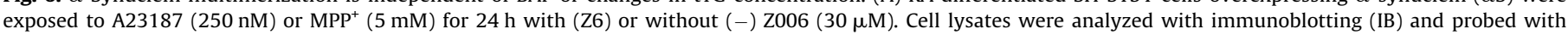

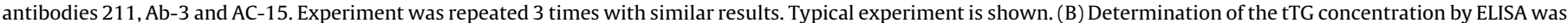

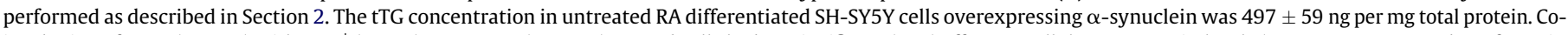

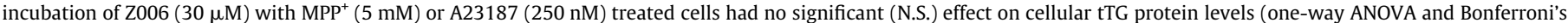

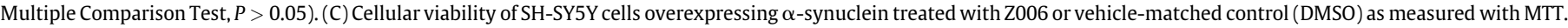

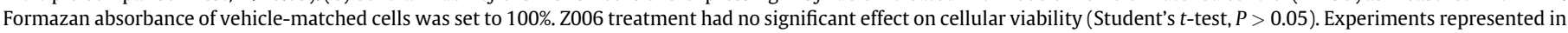
panels $\mathrm{B}$ and $\mathrm{C}$ were performed four times in triplicates and data are depicted as mean + SEM.

also using BAP incorporation in $\alpha$-synuclein overexpressing and RA-differentiated SH-SY5Y cells, Suh and coworkers failed to detect any interaction between tTG and $\alpha$-synuclein following a 20 min treatment with the potent, but highly toxic $\mathrm{Ca}^{2+}$ ionophore maitotoxin (Suh et al., 2004). In our opinion, the most likely explanation for this apparent difference in results is the relatively short incubation time with $\mathrm{Ca}^{2+}$ ionophore used by Suh et al. Also in our hands, extended periods of exposure to A23187 or $\mathrm{MPP}^{+}$ were required in order to reach detectable amounts of biotinylated $\alpha$-synuclein.

Naturally occurring polyamines, like spermine and spermidine, have been shown to stimulate $\alpha$-synuclein aggregation, albeit thus far only in vitro (Antony et al., 2003). In our in vitro setting, in the absence of tTG, neither spontaneous incorporation of BAP into $\alpha$ synuclein, nor $\alpha$-synuclein multimerization was detected (data not shown). Moreover, in our cell model omission of BAP did not prevent $\alpha$-synuclein aggregation induced by exposure to A23187 or $\mathrm{MPP}^{+}$, nor altered the ability of the tTG inhibitor Z006 to substantially inhibit this effect, thereby ruling out that effects observed in the presence of BAP were independent of tTG. Off course, in contrast to the experiments in which BAP was used, in this set of experiments where BAP was omitted, we cannot exclude the possibility that Z006 exerted its effect on $\alpha$-synuclein aggregation indirectly, rather than directly, e.g. via blockade of the interaction between tTG and another protein which influences $\alpha$-synuclein folding. Nevertheless, these data do support the notion that activation of tTG stimulates $\alpha$-synuclein multimerization. On one hand, tTG can transamidate $\alpha$-synuclein directly resulting in large multimers, consisting only of $\alpha$-synuclein, or $\alpha$ synuclein complexed with other proteins. Another explanation is that transamidated $\alpha$-synuclein monomers acts as seeds that recruit other $\alpha$-synuclein molecules thereby inducing multimerisation of $\alpha$-synuclein, as proposed by Nemes et al. (2009).

The irreversible tTG active-site inhibitors used in this study were found to have excellent in vitro enzyme activity blockade characteristics with apparent potencies in the rank order Z006 > B003 > KCC009, which compare well with data provided previously by others applying different assays (Madi et al., 2005; McConoughey et al., 2010; Schaertl et al., 2010). As expected, although maintaining similar rank order, quantitative measurement of tTG activity in living RA-differentiated wild-type SH-SY5Y cells showed that both Z006 and B003 had a reduced potency, i.e. approximately 20 -fold lower IC-50 values compared to the in vitro measurements. In our view, this may be considered as a relatively small decline in light of the large differences in experimental setup. In contrast to B003, however, Z006 retained the ability to (almost) completely inhibit tTG activity inside cells in low micromolar concentrations. Data published recently by the groups of Schaertl and McConoughey confirm our observation, that in a cellular environment Z006 shows better pharmacological characteristics as a tTG inhibitor than B003 in terms of apparent potency (McConoughey et al., 2010; Schaertl et al., 2010). Interestingly, Schaertl et al. reported a much higher cellular IC-50 value for both Z006 and B003 as compared to our results. Although this may be attributed simply to the fact that the group of Schaertl used a somewhat different assay procedure, in which incorporation of 
radiolabelled polyamine putrescine into the cellular protein fraction is measured in tTG overexpressing HEK cells, it could also point to cell-type dependent characteristics of tTG inhibition. To our knowledge, this issue has not been considered before but, in light of its potential impact on the ongoing development of tTG inhibitors for treatment of diseases affecting a large variety of cell types (Choi et al., 2005; Griffin et al., 2008; Hausch et al., 2003; McConoughey et al., 2010; Schaertl et al., 2010; Siegel and Khosla, 2007; Watts et al., 2006), deserves further consideration in future experiments.

In contrast to Z006 and B003, KCC009 failed to affect cellular tTG activity in concentrations up to $100 \mu \mathrm{M}$. For reasons discussed in Section 3, we were unable to test higher concentrations of the compound. In other studies using cultured cells KCC009 has been claimed to block tTG activity in concentrations of $100 \mu \mathrm{M}$ and above, although actual measurements of effect on ongoing tTG activity in living cells were not made (Siegel et al., 2008; Yuan et al., 2005). If correct, these data suggest that the lack of effect of KCC009 on cellular tTG activity in the present study is explained by the concentration range in which the compound was tested. However, considering our data, this would also imply that, in comparison to Z006 and B003 who show an approximately 20-fold decline between cellular and in vitro measurements (see above), a far higher reduction in apparent potency would occur for KCC009 under the experimental conditions used. KCC009 is highly lipophilic and is expected to readily pass the cell membrane. Indeed, exposure of cultured cells to KCC009 followed by cell extraction and in vitro measurement of tTG activity showed inhibition of tTG activity by residual KCC009 retained in the cell extract (Siegel et al., 2008). Therefore, the apparent failure to inhibit cellular tTG activity in concentrations up to $100 \mu \mathrm{M}$ in our experimental setup is unlikely to be due (only) to insufficient uptake. More likely, it is caused by a combination of compound characteristics, perhaps the relative instability of the reactive dihydroisoxazole moiety in KCC009 as compared to the DON group in both Z006 and B003, and prevailing conditions in the cell interior, like high concentrations of tTG protein and/or enzyme substrates. This conclusion is in line with observations made in an in vivo mouse model for chronic liver disease in which KCC009 clearly reduced overall liver injury, an effect which may be caused by interaction of the compound with tTG present at the cell surface or in the extracellular matrix (Akimov et al., 2000; Akimov and Belkin, 2001), but had no effect on tTG regulated formation of Mallory Bodies inside hepatocytes (Strnad et al., 2006). Within this context, it is also curious to note that Schaertl and coworkers reported a virtual lack of effect on intracellular enzyme activity for the large majority of tTG inhibitors tested by them (Schaertl et al., 2010). Thus, further investigation of the factor(s) determining intracellular efficacy of tTG inhibitors is clearly warranted.

Finally, tTG is increasingly recognized as a promising target to counteract protein aggregation occurring inside cells in a number of degenerative diseases. Besides $\alpha$-synuclein in PD and other synucleinopathies this includes huntingtin in Huntington's disease (Karpuj et al., 1999; Lesort et al., 1999), tau in Alzheimer's disease and related tauopathies (Johnson et al., 1997; Singer et al., 2002) and keratins in chronic liver disease (Zatloukal et al., 1992). In light of this rising interest, the selection of suitable, i.e. intracellularly active drug candidates by the use of relatively simple and reproducible cell models will become more important. In this way, large numbers of compounds may be screened before further testing in dedicated but more time-consuming cellular- and animal models. That the non-radioactive, quantitative cellular BAP protein incorporation assay as applied by us may be used for this purpose is underscored by the observation, that the maximally effective concentration of Z006 identified in this manner (i.e. $30 \mu \mathrm{M})$ was shown to reduce BAP incorporation into $\alpha$-synuclein monomers and multimers and $\alpha$-synuclein aggregation below the detection limits of the much more laborious immunoblotting assays. Therefore, taken together, our work adds to the growing body of literature on tTG inhibition as a promising target for disease modifying therapeutic strategies in PD and other protein misfolding diseases.

\section{Acknowledgement}

This work was supported by grants from the 'Stichting Internationaal Parkinson Fonds' (to B.D. and M.M.M.W.).

\section{References}

Akimov, S.S., Belkin, A.M., 2001. Cell surface tissue transglutaminase is involved in adhesion and migration of monocytic cells on fibronectin. Blood 98, 1567-1576.

Akimov, S.S., Krylov, D., Fleischman, L.F., Belkin, A.M., 2000. Tissue transglutaminase is an integrin-binding adhesion coreceptor for fibronectin. J. Cell Biol. 148, $825-838$.

Andringa, G., Lam, K.Y., Chegary, M., Wang, X., Chase, T.N., Bennett, M.C., 2004. Tissue transglutaminase catalyzes the formation of alpha-synuclein crosslinks in Parkinson's disease. FASEB J. 18, 932-934.

Antony, T., Hoyer, W., Cherny, D., Heim, G., Jovin, T.M., Subramaniam, V., 2003. Cellular polyamines promote the aggregation of alpha-synuclein. J. Biol. Chem. 278, 3235-3240.

Beck, K.E., De Girolamo, L.A., Griffin, M., Billett, E.E., 2006. The role of tissue transglutaminase in 1-methyl-4-phenylpyridinium $\left(\mathrm{MPP}^{+}\right)$-induced toxicity in differentiated human SH-SY5Y neuroblastoma cells. Neurosci. Lett. 405, 46-51.

Braak, H., Del, T.K., Rub, U., de Vos, R.A., Jansen Steur, E.N., Braak, E., 2003. Staging of brain pathology related to sporadic Parkinson's disease. Neurobiol. Aging 24, 197-211.

Breve, J.J., Drukarch, B., van Strien, M., van Dam, A.M., 2008. Validated sandwich ELISA for the quantification of tissue transglutaminase in tissue homogenates and cell lysates of multiple species. J. Immunol. Methods 332, 142-150.

Burns, R.S., Chiueh, C.C., Markey, S.P., Ebert, M.H., Jacobowitz, D.M., Kopin, I.J., 1983. A primate model of parkinsonism: selective destruction of dopaminergic neurons in the pars compacta of the substantia nigra by $\mathrm{N}$-methyl-4-phenyl1,2,3,6-tetrahydropyridine. Proc. Natl. Acad. Sci. U.S.A. 80, 4546-4550.

Chandra, S., Gallardo, G., Fernandez-Chacon, R., Schluter, O.M., Sudhof, T.C., 2005 Alpha-synuclein cooperates with CSPalpha in preventing neurodegeneration. Cell 123, 383-396.

Chartier-Harlin, M.C., Kachergus, J., Roumier, C., Mouroux, V., Douay, X., Lincoln, S., Levecque, C., Larvor, L., Andrieux, J., Hulihan, M., Waucquier, N., Defebvre, L., Amouyel, P., Farrer, M., Destee, A., 2004. Alpha-synuclein locus duplication as a cause of familial Parkinson's disease. Lancet 364, 1167-1169.

Choi, K., Siegel, M., Piper, J.L., Yuan, L., Cho, E., Strnad, P., Omary, B., Rich, K.M., Khosla, C., 2005. Chemistry and biology of dihydroisoxazole derivatives: selective inhibitors of human transglutaminase 2. Chem. Biol. 12, 469-475.

Conway, K.A., Harper, J.D., Lansbury Jr., P.T., 2000. Fibrils formed in vitro from alphasynuclein and two mutant forms linked to Parkinson's disease are typical amyloid. Biochemistry 39, 2552-2563.

Drukarch, B., Jongenelen, C.A., Schepens, E., Langeveld, C.H., Stoof, J.C., 1996. Glutathione is involved in the granular storage of dopamine in rat PC 12 pheochromocytoma cells: implications for the pathogenesis of Parkinson's disease. J. Neurosci. 16, 6038-6045.

Eliezer, D., Kutluay, E., Bussell Jr., R., Browne, G., 2001. Conformational properties of alpha-synuclein in its free and lipid-associated states. J. Mol. Biol. 307, 1061-1073.

Fesus, L., Falus, A., Erdei, A., Laki, K., 1981. Human beta 2-microglobulin is a substrate of tissue transglutaminase: polymerization in solution and on the cell surface. J. Cell Biol. 89, 706-710.

Galvin, J.E., Lee, V.M., Trojanowski, J.Q., 2001. Synucleinopathies: clinical and pathological implications. Arch. Neurol. 58, 186-190.

Gerard, M., Deleersnijder, A., Daniels, V., Schreurs, S., Munck, S., Reumers, V., Pottel, H., Engelborghs, Y., Van den, H.C., Taymans, J.M., Debyser, Z., Baekelandt, V., 2010. Inhibition of FK506 binding proteins reduces alpha-synuclein aggregation and Parkinson's disease-like pathology. J. Neurosci. 30, 2454-2463.

Gitler, A.D., Bevis, B.J., Shorter, J., Strathearn, K.E., Hamamichi, S., Su, L.J., Caldwell, K.A., Caldwell, G.A., Rochet, J.C., McCaffery, J.M., Barlowe, C., Lindquist, S., 2008 The Parkinson's disease protein alpha-synuclein disrupts cellular Rab homeostasis. Proc. Natl. Acad. Sci. U.S.A. 105, 145-150.

Griffin, M., Casadio, R., Bergamini, C.M., 2002. Transglutaminases: nature's biological glues. Biochem. J. 368, 377-396.

Griffin, M., Mongeot, A., Collighan, R., Saint, R.E., Jones, R.A., Coutts, I.G., Rathbone, D.L., 2008. Synthesis of potent water-soluble tissue transglutaminase inhibitors. Bioorg. Med. Chem. Lett. 18, 5559-5562.

Hausch, F., Halttunen, T., Maki, M., Khosla, C., 2003. Design, synthesis, and evaluation of gluten peptide analogs as selective inhibitors of human tissue transglutaminase. Chem. Biol. 10, 225-231.

Heikkila, R.E., Hess, A., Duvoisin, R.C., 1984. Dopaminergic neurotoxicity of 1methyl-4-phenyl-1,2,5,6-tetrahydropyridine in mice. Science $224,1451-1453$. 
Ibanez, P., Bonnet, A.M., Debarges, B., Lohmann, E., Tison, F., Pollak, P., Agid, Y., Durr, A., Brice, A., 2004. Causal relation between alpha-synuclein gene duplication and familial Parkinson's disease. Lancet 364, 1169-1171.

Jeitner, T.M., Fuchsbauer, H.L., Blass, J.P., Cooper, A.J., 2001. A sensitive fluorometric assay for tissue transglutaminase. Anal. Biochem. 292, 198-206.

Johnson, G.V., Cox, T.M., Lockhart, J.P., Zinnerman, M.D., Miller, M.L., Powers, R.E., 1997. Transglutaminase activity is increased in Alzheimer's disease brain. Brain Res. 751, 323-329.

Junn, E., Ronchetti, R.D., Quezado, M.M., Kim, S.Y., Mouradian, M.M., 2003. Tissue transglutaminase-induced aggregation of alpha-synuclein: implications for Lewy body formation in Parkinson's disease and dementia with Lewy bodies. Proc. Natl. Acad. Sci. U.S.A. 100, 2047-2052.

Karpuj, M.V., Garren, H., Slunt, H., Price, D.L., Gusella, J., Becher, M.W., Steinman, L., 1999. Transglutaminase aggregates huntingtin into nonamyloidogenic polymers, and its enzymatic activity increases in Huntington's disease brain nuclei. Proc. Natl. Acad. Sci. U.S.A. 96, 7388-7393.

Konno, T., Morii, T., Hirata, A., Sato, S., Oiki, S., Ikura, K., 2005. Covalent blocking of fibril formation and aggregation of intracellular amyloidgenic proteins by transglutaminase-catalyzed intramolecular cross-linking. Biochemistry 44 2072-2079.

Kruger, R., Kuhn, W., Muller, T., Woitalla, D., Graeber, M., Kosel, S., Przuntek, H., Epplen, J.T., Schols, L., Riess, O., 1998. Ala30Pro mutation in the gene encoding alpha-synuclein in Parkinson's disease. Nat. Genet. 18, 106-108.

Laemmli, U.K., 1970. Cleavage of structural proteins during the assembly of the head of bacteriophage T4. Nature 227, 680-685.

Larsen, K.E., Schmitz, Y., Troyer, M.D., Mosharov, E., Dietrich, P., Quazi, A.Z., Savalle, M., Nemani, V., Chaudhry, F.A., Edwards, R.H., Stefanis, L., Sulzer, D., 2006. Alpha-synuclein overexpression in PC12 and chromaffin cells impairs catecholamine release by interfering with a late step in exocytosis. J. Neurosci. 26 , 11915-11922.

Lashuel, H.A., Petre, B.M., Wall, J., Simon, M., Nowak, R.J., Walz, T., Lansbury Jr., P.T., 2002. Alpha-synuclein, especially the Parkinson's disease-associated mutants, forms pore-like annular and tubular protofibrils. J. Mol. Biol. 322, 1089-1102.

Lesort, M., Chun, W., Johnson, G.V., Ferrante, R.J., 1999. Tissue transglutaminase is increased in Huntington's disease brain. J. Neurochem. 73, 2018-2027.

Lesort, M., Lee, M., Tucholski, J., Johnson, G.V., 2003. Cystamine inhibits caspase activity. Implications for the treatment of polyglutamine disorders. J. Biol. Chem. 278, 3825-3830.

Lorand, L., Graham, R.M., 2003. Transglutaminases: crosslinking enzymes with pleiotropic functions. Nat. Rev. Mol. Cell Biol. 4, 140-156.

Madi, A., Karpati, L., Kovacs, A., Muszbek, L., Fesus, L., 2005. High-throughput scintillation proximity assay for transglutaminase activity measurement. Anal. Biochem. 343, 256-262.

McConoughey, S.J., Basso, M. Niatsetskaya, Z.V., Sleiman, S.F., Smirnova, N.A. Langley, B.C., Mahishi, L., Cooper, A.J., Antonyak, M.A., Cerione, R.A., Li, B., Starkov, A., Chaturvedi, R.K., Beal, M.F., Coppola, G., Geschwind, D.H., Ryu, H. Xia, L., Iismaa, S.E., Pallos, J., Pasternack, R., Hils, M., Fan, J., Raymond, L.A., Marsh, J.L., Thompson, L.M., Ratan, R.R., 2010. Inhibition of transglutaminase 2 mitigates transcriptional dysregulation in models of Huntington disease. EMBO Mol. Med. 9, 335-337.

Nemes, Z Petrovski, G., Aerts, M. Sergeant, K, Devreese, B, Fesus, L, 2009. Transglutaminase-mediated intramolecular cross-linking of membrane-bound alpha-synuclein promotes amyloid formation in Lewy bodies. J. Biol. Chem. 284 $27252-27264$.

Pahlman, S., Ruusala, A.I., Abrahamsson, L., Mattsson, M.E., Esscher, T., 1984. Retinoic acid-induced differentiation of cultured human neuroblastoma cells: a comparison with phorbolester-induced differentiation. Cell Differ. 14, $135-144$

Polymeropoulos, M.H., Lavedan, C., Leroy, E., Ide, S.E., Dehejia, A., Dutra, A., Pike, B. Root, H., Rubenstein, J., Boyer, R., Stenroos, E.S., Chandrasekharappa, S., Athanassiadou, A., Papapetropoulos, T., Johnson, W.G., Lazzarini, A.M., Duvoisin, R.C. Di, I.G., Golbe, L.I., Nussbaum, R.L., 1997. Mutation in the alpha-synuclein gene identified in families with Parkinson's disease. Science 276, 2045-2047.
Schaertl, S., Prime, M., Wityak, J., Dominquez, C., Munoz-Sanjuan, I., Pacifici, R.E., Courtney, S., Scheel, A., Macdonald, D., 2010. A profiling platform for the characterization of transglutaminase 2 (TG2) inhibitors. J. Biomol. Screen. 15 (5), 478-487.

Schmid, A.W., Chiappe, D., Pignat, V., Grimminger, V., Hang, I., Moniatte, M., Lashuel H.A., 2009. Dissecting the mechanisms of tissue transglutaminase-induced cross-linking of alpha-synuclein: implications for the pathogenesis of Parkinson disease. J. Biol. Chem. 284, 13128-13142.

Schule, B., Pera, R.A., Langston, J.W., 2009. Can cellular models revolutionize drug discovery in Parkinson's disease? Biochim. Biophys. Acta 1792, 1043-1051.

Segers-Nolten, I.M., Wilhelmus, M.M., Veldhuis, G., van Rooijen, B.D., Drukarch, B., Subramaniam, V., 2008. Tissue transglutaminase modulates alpha-synuclein oligomerization. Protein Sci. 17, 1395-1402.

Siegel, M., Khosla, C., 2007. Transglutaminase 2 inhibitors and their therapeutic role in disease states. Pharmacol. Ther. 115, 232-245.

Siegel, M., Strnad, P., Watts, R.E., Choi, K., Jabri, B., Omary, M.B., Khosla, C., 2008 Extracellular transglutaminase 2 is catalytically inactive, but is transiently activated upon tissue injury. PLoS ONE 3, e1861.

Singer, S.M., Zainelli, G.M., Norlund, M.A., Lee, J.M., Muma, N.A., 2002 Transglutaminase bonds in neurofibrillary tangles and paired helical filament tau early in Alzheimer's disease. Neurochem. Int. 40, 17-30.

Singh, U.S., Pan, J., Kao, Y.L., Joshi, S., Young, K.L., Baker, K.M., 2003. Tissue transglutaminase mediates activation of RhoA and MAP kinase pathways during retinoic acid-induced neuronal differentiation of SH-SY5Y cells. J. Biol. Chem. 278, 391-399.

Spillantini, M.G., Schmidt, M.L., Lee, V.M., Trojanowski, J.Q., Jakes, R., Goedert, M., 1997. Alpha-synuclein in Lewy bodies. Nature 388, 839-840.

Strnad, P., Siegel, M., Toivola, D.M., Choi, K., Kosek, J.C., Khosla, C., Omary, M.B., 2006. Pharmacologic transglutaminase inhibition attenuates drug-primed liver hypertrophy but not Mallory body formation. FEBS Lett. 580, 2351-2357.

Suh, M.D., Park, C.H., Kim, S.S., Kil, M.O., Lee, G.H., Johnson, G.V., Chun, W., 2004 Tissue transglutaminase is not involved in the aggregate formation of stably expressed alpha-synuclein in SH-SY5Y human neuroblastoma cells. Arch. Pharm. Res. 27, 850-856.

Ulmer, T.S., Bax, A., Cole, N.B., Nussbaum, R.L., 2005. Structure and dynamics of micelle-bound human alpha-synuclein. J. Biol. Chem. 280, 9595-9603.

Uversky, V.N., 2007. Neuropathology, biochemistry, and biophysics of alphasynuclein aggregation. J. Neurochem. 103, 17-37.

Vermes, I., Steur, E.N., Jirikowski, G.F., Haanen, C., 2004. Elevated concentration of cerebrospinal fluid tissue transglutaminase in Parkinson's disease indicating apoptosis. Mov. Disord. 19, 1252-1254.

Watts, R.E., Siegel, M., Khosla, C., 2006. Structure-activity relationship analysis of the selective inhibition of transglutaminase 2 by dihydroisoxazoles. J. Med. Chem. 49, 7493-7501.

Weinreb, P.H., Zhen, W., Poon, A.W., Conway, K.A., Lansbury Jr., P.T., 1996. NACP, a protein implicated in Alzheimer's disease and learning, is natively unfolded. Biochemistry 35, 13709-13715.

Wilhelmus, M.M., van Dam, A.M., Drukarch, B., 2008. Tissue transglutaminase: a novel pharmacological target in preventing toxic protein aggregation in neurodegenerative diseases. Eur. J. Pharmacol. 585, 464-472.

Yuan, L., Choi, K., Khosla, C., Zheng, X., Higashikubo, R., Chicoine, M.R., Rich, K.M., 2005. Tissue transglutaminase 2 inhibition promotes cell death and chemosensitivity in glioblastomas. Mol. Cancer Ther. 4, 1293-1302.

Zarranz, J.J., Alegre, J., Gomez-Esteban, J.C., Lezcano, E., Ros, R., Ampuero, I., Vidal, L., Hoenicka, J., Rodriguez, O., Atares, B., Llorens, V., Gomez, T.E., del, S.T., Munoz, D.G., de Yebenes, J.G., 2004. The new mutation, E46K, of alpha-synuclein causes Parkinson and Lewy body dementia. Ann. Neurol. 55, 164-173.

Zatloukal, K., Fesus, L., Denk, H., Tarcsa, E., Spurej, G., Bock, G., 1992. High amount of epsilon-(gamma-glutamyl)lysine cross-links in Mallory bodies. Lab Invest 66, 774-777.

Zhang, J., Lesort, M., Guttmann, R.P., Johnson, G.V., 1998. Modulation of the in situ activity of tissue transglutaminase by calcium and GTP. J. Biol. Chem. 273, 2288-2295. 